\title{
Human Capital Investment And Training In Islamic Banking Industry In Jordan Jordan Islamic Bank for Finance and Investment
}

\author{
Dr. Ziad Mohammad Obeidat \\ Faculty of Business\&Finance, Islamic banking Department \\ The World Islamic Science \& Education
}

doi: 10.19044/esj.2016.v12n10p90 URL:http://dx.doi.org/10.19044/esj.2016.v12n10p90

\begin{abstract}
The purpose of this study is to measure the impact of investment in human resources activities on the effectiveness of investment in human capital and investigated the relationship between human capital Investmenttraining and its effectiveness in Islamic banks in Jordan. The fascinating development and point of discussion in recent years is the rapid growth and expansion of the Islamic financial services industry. It is no longer rhetoric as Islamic finance has been accepted as viable and competitive mode of financial intermediation that offers wide range of financial products and services to meet the highly differentiated demands of the new economy; not only in Muslim countries but also beyond the Muslim world. Against these rapid revolution of Islamic financial industry globally and in Jordan particularly, human capital has become the defining factor in sustaining the performance and competitiveness of Islamic financial industry. Thus it is crucial to place strong focus on human capital development in embarking Islamic financial services encompassing the basic foundation namely; education. A prerequisite requirement for highly talented and skilled labor force is essential to maximize the opportunities presented by the evolving economic environment in the future. The objective of this study is to determine the issues faced by practitioners that initiate the need to undertake training and development courses as well as to identify the type of training required by current practitioners that affect performance. The main findings of the study can be more comprehensive and representative if more respondents from several banks that practices Islamic finance can be involved in validating the issue that is realizable for future study
\end{abstract}

Keywords: Training and Development, Islamic Banking, Human Capital Development 


\section{Introduction}

Islamic financial service is one of the fastest growing industries in Jordan today and has now been accepted as viable and competitive mode of financial intermediaries. Islamic banking has undertaken a long journey over the past three decades and undeniably faces numerous challenges that need to be addressed in order.

To provide a sound base for future course (Khan, 2007). The accelerating pace of financial integration is leading towards prospects to expand beyond domestic borders that capture opportunities from regional and global markets of financial institutions (Zeti, 2007). The competitiveness and circumstances of financial environments are the drivers that determine the survival of Islamic banking.

One of the strategic ways to survive and compete amongst Islamic banks is imposition of training and development modules as part of human development capabilities lays fundamental needs of enhancing and improving knowledge as well as skills of employees. Proper training identification and major allocation of budget towards training is one of the major successes in implementing training initiatives. Therefore training and development become one of the most critical aspects of human resources management (HRM) effectiveness (Abdelgadir \& Garunis, 2001). This paper illustrates training and development as the basic development of human capital that acts as contributing factor to financial institutions towards positive attitude, knowledge and skillful workers leading to competitive advantage in Islamic financial products and services. Subsequently this paper identifies the specific areas of training viewed as the most important to practitioners in enhancing competencies to sustain in Islamic banking industry.

\section{The challenges and the future}

Notwithstanding the encouraging data, the industry is small compared to the size of its potential market. However the encouraging success shown by many local banks signifies the demand of Islamic financial industry for more accelerating expansion and moving towards popular choice among consumers. The emergence of new player creates challenges among Malaysian commercial banks not limited to competition of conventional products but also with new competitors that offer Islamic based products (Ahmad, 2004). The continued progression in the economy and financial landscape presented many opportunities for new products, services and innovations (Zeti, 2007). With this changes and further capability of Islamic financial services prove the offer of alternative banking on top of conventional banking transactions as no longer disputable. Nonetheless progression of Islamic banking faces challenges that need to be addressed in 
order to promote acceptability and stability of the industry.

A joint report initiates by Islamic Research \& Training Institute Islamic Development Bank (IRTISDB) and Islamic Financial Services Board (IFSB) points out one of the challenges as fulfillment of human resource requirements (Khan, 2007). Zeti (2006) further reiterate that the rapid evolution of Islamic financial industry and the growing significance of Islamic financial institutions globally are in need of skilled human capital as the focal point in sustaining performance and competitiveness of Islamic financial services industry. The common view initiates important correlation between human capital and business survival in today's competitive environment. Successful companies are those that understand the importance of managing and organizing the use of human capital (Gordon, 2006). According to him one of the many ways to improve human assets includes education and training that ensure performance, qualified people and motivate employees.

Therefore organizations continue the search for innovative approaches to increase competitive advantage in this age which is defined by utilization of people's talent (Brooks et al., 2006). In realizing this strategic value, organization has to device effective and workable human capital initiatives that can be utilize as a long term planning. In fact; human capital rather than physical or financial capital distinguishes leaders in the market (khamis, 2003). Picket (2005) identifies effective organizations are those that possess superior strategies for managing and developing people, focus on individual and organizational capability, measure people as an assets as well as a cost and able to resist the short-run pressures that cause constant underinvestment in people. Attributable to this the role of training and development in contemporary personnel or human resource function as the basic development of human capital form the basis of this study.

\section{LITERATURE REVIEW Human Capital and Organization Development}

Undoubtedly in current competitive business environment; people play an important role in the survival of any business organizations. Human resources or human capital are now seen as one of the major contributors to competitiveness and human resource dimension should be taken into account before embarking decisions and implementing new corporate strategy (Morrow, 2001). For many, sidelining this important element invite disaster to which not only losing competitiveness but as well crippling the process of production. Therefore human resources or capital may be regarded as the most valuable asset of any enterprises. As continuation to confirm the relevancy of company's human resources or human capital; skills, knowledge, commitment and motivation are the prime factors that require encouragements and enhancements. In this context they need to be 
developed and therefore, continuous training plays an important role (Vermeulen \& Crous, 2000).

General Accounting Office (GAO, 2002) defines human capital as people and people are assets whose value can be enhanced through investment. Similar to all other investments, the goal is to maximize value while managing risk. Investment in people is not limited to providing training and development but encompass rewards and benefits offered to employees. As cited by Fong \& Yorston (2003) the term human capital is first used by Nobel Laureate, Theodore w. Schultz, in the 1961 American Economic Review Journal titled, 'Investment in Human Capital'. The term is now most frequently used to refer to a combination of skills, experience and knowledge. From the human capital perspective, employees are viewed as capital resource that requires investment (sabi, 1996). According to Chartered Institute of Personnel and Development (CIPD, 2007) human capital is knowledge, skills, abilities and capacity possessed by people in an organization in order to develop and innovate.

The economic definitive meaning of human capital by Wikipedia refers to the stock of productive skills and technical knowledge embodied in labor. Many early economic theories refer to it simply as labor; one of the three factors of production considered to be fungible resource i.e. homogeneous and easily interchangeable. Other conceptions of labor dispense with these assumptions. Aziz (2007) further redefine human capital as incorporation of human intellect, labor, workforce and human strengths in the form of employees, customers, business partners and competitors. As an investment; Thomas Davenport, a management consultant; has combined several of these definitions leading to human capital investment as ability, knowledge, skill, and talent in addition to behavior (Fong \&Yorston, 2003). Quality human capital therefore provide for competent workforce that ensure competency of performing jobs and training and development are the main platforms adapted by human resource division of an organizations for many decades.

Current global competitiveness and technological development require creation of new knowledge communicated to employees and leads to continuous innovation (Horwitz, 1999). Improving product and service quality may require devolution of authority and responsibility to employees at lower levels. Integrated systemic changes in organizational design with de-layered structures, flexible work practices including task or functional flexibility and multi-skilling creates new challenges for human resource development (Horwitz, 1999). According to Snyder and Cummings (1998) as cited by Reed \& Vakola (2006); organizations' abilities to change are necessary for survival. The capacity of change is associated with organizational learning since organizations have to be able to learn from past 
experiences, effectively use "lessons learnt" correct errors and disseminate knowledge within the organization in order to change and adapt themselves to the continuously changing market. Increased needs for improved performance requires efficient ways to identify, recruit, measure and improve the training and education of workforce (Berge et al., 2002).

If people are to do things better, they must not only want to do things differently, they must have the skills and knowledge to do so (Vermeulen, \& Crous, 2000). Hence human resource development is a process of developing and/or unleashing expertise through organization development (OD) and personnel training and development for the purpose of improving performance (Swanson, 2001 as cited by Saleh, 2005). This view is supported by Antonacopoulou (1999) as cited by David Robotham (2004) who, from an extensive review of the management development literature, concluded that learning is an integral part of human resource development process. Ashton and Felstead (1995) as cited by Morrow (2001) as well acknowledge the widespread consensus that training and development should be encouraged. The best way to institute quality into an organization, particularly a bank, is to train employees to perform better. As example, First Interstate Bancorp demonstrate confidence in employee training by initiating credit training programmers for employees involved in the analysis, recommendation, approval or review of commercial credits (Spagnola \& Spagnola, 1993, as cited by Vermeulen \& Crous, 2000).

The importance of effective education and training is emphasized by many authors and Bird (1993) sees training as important in providing employees the necessary knowledge that enhance quality across the company. Batten (1992) as cited by Vermeulen\& Crous (2000) describes the importance of education and training by the following words: "Train, Train and Train!”. McDonnell (1994), Schonberg (1992) and Samad (1995) regard training as fundamental to transform workforce that allow usability in the demanding TQM environment. On the contrary, companies should be looking more inwardly of training and development of existing employees rather than buying in qualified and experienced workers (Morrow, 2001).

\section{Training and Development in Islamic Banking}

According to Institute of Islamic Banking and Insurance one of the primary objective of trainings in Islamic banking is building the knowledge and human resource skills base that enhances competency of personnel serving in this sector with genuine realization on the serious need to undertake morality and professionalism into account in all business dealings. However, in undertaking many training initiatives; the important factor to be considered is the focus areas of training. In the case of Islamic Banking, training is not just involving matters on operational factors, products 
knowledge or other soft skills, but most importantly are the knowledge on Shariah. Shariah knowledge is the fundamental and imperative prerequisite prior to embankments of Islamic banking activities that creates differentiation of conventional banking. Gait \& Worthington (2008) confirms the quintessential of Shariah knowledge by defining Islamic finance or banking as financial service or product that is principally implemented in compliance to the main tenets of Shariah.

For Islamic community, Islamic banking is not merely having an account or loan that is Islamic in nature but the people of relevant institution should be well versed in Shariah knowledge as well. Shariah, is define as a system of ethics and values covering all aspects of life i.e. personal, social, political, economic, and intellectual with unchanging bearings as well as major means of adjusting to change as inseparable from Islam's basic beliefs, values and objectives (Dusuki \& Irwani , 2008). In practice, the advocator or provider of any training that involve Islamic banking should not short change or sacrificed Shariah sentiment in undertaking of these training.

\section{Methodology}

A set of questionnaires consisting of 31 questions and 4 parts is developed. All questions are based on Likert scale which ranked between 1 to 5 with 1 being strongly agreed and 5 being strongly disagree. The set of questionnaires is distributed to practitioners comprising of Branch Managers, Heads of Department and Executives Jordan Islamic bank. A total of 140 set of questionnaires is being distributed and 60 (43\%) of them was returned.

The questionnaire is divided into three sections. The first section of the questionnaire is on demographic information of respondent. The subsequent section is designed to determine the issues faced by practitioners that initiate the need to undertake training and development courses. And the last section is to identify the type of training required by current practitioners that affect performances.

The statistical analysis for the first section is descriptive statistic while the second section is subjected to reliability and validity testing followed by Pearson Correlation analysis. Consequently the statistical analysis for the third section is reliability and validity testing supported by Principal Component Analysis. Ultimately Multiple Linear Regression analysis is performed in order to identify the relationship between the type of training and development to the human capital performance.

\section{Findings}

Table 1 reports the outcome of descriptive statistics for the first section. It is shown that more male respondent participating in this survey and majority belongs to the age of more than 25 years old. Most of the 
respondents are executives and senior executives who have served the company for more than 5 years.

\begin{tabular}{|c|c|c|}
\hline \multicolumn{2}{|c|}{ Table 1: Descriptive Statistics on Demographic Information of Respondent } \\
\hline \multirow{4}{*}{ Gender } & Male & $66.7 \%$ \\
\cline { 2 - 3 } & Female & $33.3 \%$ \\
\hline \multirow{4}{*}{ Age } & Less than 25 years & $6.7 \%$ \\
\cline { 2 - 3 } & Between 25 to 35 & $30 \%$ \\
\cline { 2 - 3 } & Between 35 to 45 & $25 \%$ \\
\cline { 2 - 3 } & More than 45 & $38.3 \%$ \\
\hline \multirow{5}{*}{ Position } & Officers & 15.0 \\
\cline { 2 - 3 } & Executives & 40.0 \\
\cline { 2 - 3 } & Senior Executives & 26.7 \\
\cline { 2 - 3 } & Managers & 13.3 \\
\cline { 2 - 3 } & Above Managers & 1.7 \\
\cline { 2 - 3 } & Others & 3.3 \\
\hline \multirow{5}{*}{ Length of Services } & Less than 1 year & 5.0 \\
\cline { 2 - 3 } & Between 1 to 3 years & 15.0 \\
\cline { 2 - 3 } & Between 3 to 5 years & 5.0 \\
\cline { 2 - 3 } & More than 5 vears & 75.0 \\
\hline
\end{tabular}

Table 2 reports the finding for the second section of the survey. The outcome begins with the result of reliability testing of Cronbach's Alpha with the value of 0.793 . The result of KMO Bartlett Test is 0.705 while the Pearson Correlation Analysis suggests statistical significance on bi-variety correlation between the issues faced by practitioner to the need of undertaking training and development courses. Thus the result indicates that practitioners do face difficulties in explaining to potential customer on Shariah concept as well as Islamic banking product. As such the lack of knowledge limits their contribution to develop Islamic banking and finance product that initiate as well as motivate their needs to undergo training and development courses.

The result for the third section of the survey begins with the report in Table 3. The Cronbach's Alpha on the first construct of Shariah knowledge related training is reported as 0.943 supported by the KMO value of 0.867 .

\begin{tabular}{|c|c|c|}
\hline \multicolumn{3}{|c|}{$\begin{array}{l}\text { Table 2: Reliability, Validity and Pearson Correlation Analysis of Issues Faced by } \\
\text { Practitioners }\end{array}$} \\
\hline \multicolumn{2}{|c|}{ Cronbach's Alpha Based on Standardized Items } & .793 \\
\hline \multicolumn{2}{|c|}{ Kaiser-Meyer-Olkin Measure of Sampling Adequacy } & .705 \\
\hline \multicolumn{2}{|c|}{ Bartlett's Test of Sphericity } & $78.538 * *$ \\
\hline \multirow[t]{3}{*}{ Pearson Correlation } & Explain Shariah Concept & $.353 * *$ \\
\hline & Explain Islamic Banking Product & $.424 * *$ \\
\hline & Contribution to Product Development & $.535 * *$ \\
\hline
\end{tabular}

Table 2-6: Descriptive Statistics on Demographic Information of Respondent 


\section{The Principal Component}

Analysis suggests that only one component is being extracted for the construct with the total variance explained of $85.483 \%$. The component named as knowledge is use in the multiple linear regression that identify the type of training that should be offered to the employees in order to improve their performance.

(Table -3- Cronbach's Alpha Based on Standardized Items)

\begin{tabular}{|c|c|c|}
\hline \multicolumn{3}{|c|}{$\begin{array}{l}\text { Table 2: Reliability, Validity and Pearson Correlation Analysis of Issues Faced by } \\
\text { Practitioners }\end{array}$} \\
\hline \multicolumn{2}{|c|}{ Cronbach's Alpha Based on Standardized Items } & .793 \\
\hline \multicolumn{2}{|c|}{ Kaiser-Meyer-Olkin Measure of Sampling Adequacy } & .705 \\
\hline \multicolumn{2}{|c|}{ Bartlett's Test of Sphericity } & $78.538 * *$ \\
\hline \multirow[t]{3}{*}{ Pearson Correlation } & Explain Shariah Concept & $.353 * *$ \\
\hline & Explain Islamic Banking Product & $.424 * *$ \\
\hline & Fontrihution to Drndurt Mavalnn & $525 *$ \\
\hline
\end{tabular}

The Cronbach's Alpha on the second construct of collaborative training is reported as (Table 4- Cronbach's Alpha Based on Standardized Items)

\begin{tabular}{|c|c|c|}
\hline \multicolumn{3}{|c|}{$\begin{array}{l}\text { Table 2: Reliability, Validity and Pearson Correlation Analysis of Issues Faced by } \\
\text { Practitioners }\end{array}$} \\
\hline \multicolumn{2}{|c|}{ Cronbach's Alpha Based on Standardized Items } & .793 \\
\hline \multicolumn{2}{|c|}{ Kaiser-Meyer-Olkin Measure of Sampling Adequacy } & .705 \\
\hline \multicolumn{2}{|c|}{ Bartlett's Test of Sphericity } & $78.538 * *$ \\
\hline \multirow[t]{3}{*}{ Pearson Correlation } & Explain Shariah Concept & $.353 * *$ \\
\hline & Explain Islamic Banking Product & $.424 * *$ \\
\hline & Contribution to Product Development & $.535 * *$ \\
\hline
\end{tabular}

0.781 supported by the KMO value of 0.676 as reported in Table 4 below. The Principal Component analysis suggests that only one component is being extracted for the construct with the total variance explained of $70.004 \%$. The component named as collaborative training is use in the linear regression.

Table 5

Table 5 reports the outcome of Cronbach's Alpha as 0.816 followed by the KMO value of 0.500 for the third construct of the third section that is continuous training. The outcome of Principal Component analysis suggests that one component is extracted for the construct with the total variance explained of $86.677 \%$. The component is identified as continuous training and used in the multiple linear regressions to determine the type of training employees' should attend to improve their performance.

Table 6 reveals the outcome of the Multiple Linear Regression between the types of training required by employees to improve their job performance. The adjusted $\mathrm{R}$ square for the regression is at acceptable level of 0.319 with the p-value of $\mathrm{F}$ 
(Table 5\&6 reveals the outcome of the Multiple Linear Regression

\begin{tabular}{|c|c|c|}
\hline \multicolumn{3}{|c|}{$\begin{array}{l}\text { Table 2: Reliability, Validity and Pearson Correlation Analysis of Issues Faced by } \\
\text { Practitioners }\end{array}$} \\
\hline \multicolumn{2}{|c|}{ Cronbach's Alpha Based on Standardized Items } & .793 \\
\hline \multicolumn{2}{|c|}{ Kaiser-Meyer-Olkin Measure of Sampling Adequacy } & .705 \\
\hline \multicolumn{2}{|c|}{ Bartlett's Test of Sphericity } & $78.538 * *$ \\
\hline \multirow[t]{3}{*}{ Pearson Correlation } & Explain Shariah Concept & $.353 * *$ \\
\hline & Explain Islamic Banking Product & $.424 * *$ \\
\hline & Contribution to Product Development & $.535 * *$ \\
\hline
\end{tabular}

Statistic reported as less than 0.005 . Thus the independent variables jointly explained the changes in the dependent variable. The p-value of Shariah knowledge related training is 0.076 hence this type of training is

\begin{tabular}{|c|c|c|}
\hline \multicolumn{3}{|c|}{$\begin{array}{l}\text { Table 2: Reliability, Validity and Pearson Correlation Analysis of Issues Faced by } \\
\text { Practitioners }\end{array}$} \\
\hline \multicolumn{2}{|c|}{ Cronbach's Alpha Based on Standardized Items } & .793 \\
\hline \multicolumn{2}{|c|}{ Kaiser-Meyer-Olkin Measure of Sampling Adequacy } & .705 \\
\hline \multicolumn{2}{|c|}{ Bartlett's Test of Sphericity } & $78.538 * *$ \\
\hline \multirow[t]{3}{*}{ Pearson Correlation } & Explain Shariah Concept & $.353 * *$ \\
\hline & Explain Islamic Banking Product & $.424 * *$ \\
\hline & Contribution to Product Development & $.535 * *$ \\
\hline
\end{tabular}

statistically significance at the $10 \%$ level. Nevertheless the p-value of collaborative and continuous training is more than $10 \%$ level of significance thus, it is concluded that this type of training is not required by practitioners to improve their work performance. Therefore the emphasis of improving the human capital in Islamic banking should be made in the area of enhancing. Shariah knowledge of practitioners rather than either consistent training or collaboration of training program with others.

\section{Discussion}

Looking again at the four key policy of HRM, the three operational goals of commitment, flexibility and high quality are all intrinsically linked to training and development. Employees who are highly trained and whose career development is effectively managed by the company show high levels of commitment, flexible, invariably multi-skilled and able to produce significant contributions to the quality of goods and services the company offers, regardless of the level they operate (Morrow, 2001). The roles of training comprehend the required and acceptable level of competencies which enable organizations to compete.

In the mid-2000s a team of researchers from Charles Stuart University and from the University of Technology Sydney carried out two 
major projects that examine the determinants of employer training. The research confirmed the growing strength of association between training and human resource development (Smith, 2006). The research confirmed the increasing strength of association between the three classic elements of human resource development - individual career development, organizational development and training (Mulligan, 1989 cited by Smith, 2006).

Many organizations today are shaping their training towards fulfillment of individualized needs in order to enhance performance (Smith, 2006). Combination of training and development with proper execution and monitoring inculcate progressively the wealth of human capital consisting of skills, knowledge and positive attitude. The outcome is not merely capable workforce or quality human capital but as well as a wide spectrum of career enhancement in which employer has to honor. Additionally many organizations such as the banking sector imposed and ensure certain percentage of total employee gross salary is budgeted for training. And on part of the employee; fulfilling certain number of hours of job commitment towards training is part of performance indicators. In the case of Malaysia, the formation of Islamic Banking and Finance Institute (IBFIM), International Centre for Education in Islamic Finance (INCEIF), Malaysian International Islamic Centre (MIFC) and Shariah Knowledge Center that exist in most Islamic and Commercial banks are indicators as well as initiatives toward realizing and supporting the importance of training and development for the growth of Islamic finance. The fast growth of Islamic based financing and the diligent actions of government in supporting financial institutions to adopt and practice banking services division on Islamic principals sees the role of training becoming more critical in familiarizing and understanding Islamic concepts and practices.

Ultimately the respondents are in agreement that lack of Shariah knowledge causes difficulties to explain well to customers and limit contributions to the company in Islamic products development that initiate the need to undergo training and development. It is concluded that the most sought after training to improve job performance is the Shariah knowledge related training. Nonetheless the findings conclude collaborative as well as continuous training is not the main concern. The conclusion indicates that it does not matter who deliver the training as well as consistent participation in training program rather the outcome of possessing the knowledge is crucial.

\section{Limitations and future study}

Generally the study can be more comprehensive and representative if more respondents from several banks that practices Islamic finance can be involved in validating the issue that is realizable for future study. However 
the study itself gives several snapshots on the importance of training and development as well as on the type of training for the future of Islamic banking in competing with sophisticated conventional banks. Compelling for future studies; many aspects and parameters can be divulged to analyze the development of effective human capital in order to sustain the demand of today's organization.

\section{Summary}

The study is performed with involvement of practitioners in order to venture the insight view of Islamic Banking environment in Jordan after being extensively promoted and supported by the government. However, despite the aggressive actions taken by Jordan government in promoting Jordan as the Islamic banking and financing hub, Jordan still require skilled human capital or expertise to enhance and nurture the industry. It is concluded in this paper, that one of the urgent and consistent action required for Jordanian Islamic banking industry is the generation of human capital or expertise in the aspect of Islamic banking operation which is currently a thin adaptation of conventional banking operation that filled the industry with insufficient human capital of admirable Shariah knowledge.

The lingering observation of limited Shariah knowledge expertise, the limited knowledge on Islamic banking product of employees and the lack of capability and skills to develop Islamic banking product itself require prompt intervention through training initiatives. Further, the current training and development initiated by financial institutions need to be intensive and revamp for employees to be fluent in Islamic banking may it be in term of operation, Shariah knowledge and products. Due to this, for Islamic banking industry in Jordan to be able to grasp the opportunity in this evolving industry, actions need to be taken in the area of training and development particularly on Shariah knowledge related training apart from promising career development of human resources in order to solve the above issues by means of extensive and comprehensive training. In summary, training and education is for everybody in the organizations, although the training contents may differ, it is essential that everybody should be able, with the aid of the necessary training, to make a vast contribution to the improvement of total quality in an organization (Vermeulen \& Crous, 2000).

\section{References:}

Abdelgadir, N. A. and Elbadri, G., "Training Practices Of Polish Companies: An Appraisal and Agenda For Improvement”, Journal of European Industrial Training, 2001, Vol. 25, No. 2/3/4, pp. 69-79. Antonacopoulou, E. P., "Reconnecting Education, Development and Training Through Learning: A Holographic Perspective”, Education and Training, 1999, Vol 42, No. 4/5. 
Aziz, Q., "Human Capital Optimization”, Proceeding from Human Capital Optimization: Strategies, Challenges and Sustainability, 2007, December16 $-18$.

Ahmed, M. (2004), "Islamic Versus Traditional Banking in Arab Region: Premises And Promises", paper presented to the International Seminar on "The Prospects of Arab Economic Cooperation", Alexandria, Egypt.

Berge, Z.; Marie, D. V.; Nancy, B.; Linda, D. and Donna, S., "The Increasing Scope Of Training And Development Competency", Benchmarking: An International Journal, 2002, Vole 9, No. 1.

Brooks, K. \& Nafukho., "Human Resource Development, Social Capital, Emotional Intelligence, Any Link to Productivity?” Journal of European Industrial Training, 2006, Vol. 30 No 2, pp. 117-128.

Chartered Institute of Personnel and Development (CIPD), "Human Capital", CIPD Factsheet November, 2007, Available at http://www.cipd.co.uk/subjects/corpstrtgy/hmncapital

Dusuki A.W. and Irwani, N., "Maqasid al-Shariah, Maslahah, and Corporate Social Responsibility", The American Journal of Islamic Social Sciences, 2008, Vol. 24 No.1, pp. 25 - 45.

General Accounting Office (GOA), "A Model of Strategic Human Capital Management”, GAO United State, 2002, Available at www.gao.gov/cgibin/getrpt?GAO-02-373SP

Gordon, A., "Technique to Improve Human Capital", Ezine Articles, December 14, 2006, Available at http//EzineArticles.com/?expert =Alexander Gordon

Haron, S.; Ahmad, N. and Planisek, S. L., "Bank Patronage Factors of Muslim and Non-Muslim Customers", International Journal of Bank Marketing, 1994, Vol. 12 No. 1, pp. 32-40.

Horwitz, F. M., "The Emergence of Strategic Training and Development: The Current State Of Play", Journal of European Industrial Training, 1999, Vol. 23, No. 4/5.

Institute of Islamic Banking and Insurance, “Training”, 1999, Available from http://www.islamic-banking.com/training.aspx, accessed on $21^{\text {st }}$ October 2010

IBF NET (2004), Islamic banks and financial institutions, September 2004.

IIAB - Islamic International Arab Bank (2002), “Annual Report”, Amman, Jordan

IIAB - Islamic International Arab Bank (2004), “Annual Report”, Amman, Jordan

JIB - Jordan Investment Bank (2005), "Finance and Banking”, on line available at

http://www.jordaninvestment.com/2c.htm, retrieved on 9/24/2005. 
JIBFI - Jordan Islamic Bank for Finance and Investment (2003), “Annual Report”, Amman, Jordan.

JIBFI - Jordan Islamic Bank for Finance and Investment (2004), "Annual Report”, Amman, Jordan.

Kee, F. and Yorston, R., "Human Capital Measurement", London Business School, June 2003, Available at http://www.berr.gov.uk/files/file38840.pdf JIB - Jordan Investment Bank (2005), "Finance and Banking”, on line available at http://www.jordaninvestment.com/2c.htm, retrieved on 9/24/2005.

JIBFI - Jordan Islamic Bank for Finance and Investment (2003), "Annual Report”, Amman, Jordan.

JIBFI - Jordan Islamic Bank for Finance and Investment (2004), "Annual Report”, Amman, Jordan. 19

JIR - Jordanian Information Resource (2005), "Banking and Finance”, on line Available at http://reference.allrefer.com/country-guide-study/jordan/, retrieved on 9/9/2005

Khamis, M. (2003), "Financial Sector Reforms and Issues in Jordan", Central Bank of Jordan, paper presented to the Euro-Med Regional Economic Dialogue, Rome.

Sabi, M. (1996) "Comparative Analysis of Foreign and Domestic Bank Operation in Hungary”, Journal of Comparative Economics, Vol. 22, pp. 179-188.

Saidi N. (2004), "Financial Sector Development and Reform”, Economic Research Forum (ERF) studies, Vol. 11, No. 2, pp. 9-13.

Saleh, A. S. and Z. Rami (2005), "Development of Islamic Banking in Lebanon: Prospects and Future Challenges”, Review of Islamic Economics, Vol. 9, No.2, pp. 72-91.

Samad, A. (1999), "Comparative Efficiency of the Islamic Bank Malaysia vis-à-vis Conventional Banks”, Journal of Economics and Management, Vol. 7, No. 1.

Khan, T. , "The Islamic Financial Services Industry :Ten-Year Framework and Strategies”, Islamic Research \& Training Institute Islamic Development Bank, Islamic Financial Services Board and Islamic Research and Training Institute, April 5, 2007.

Morrow, T., "Training and Development In The Northern Ireland Clothing Industry”, Journal of European Industrial Training, 2001, Vol. 25, No. 2/3/4.

Ariff, M., "Islamic Banking: A Variation Of Conventional Banking?", Monash Business Review, 2007, Vol. 3/1, pp. 1-7.

Odini, C., "Training and Development Of Skills In A Changing Information Environment”, Change?”, Journal of Organizational Change Management, 2006, Vol. 19 No. 3, pp. 393-407. Robotham, D., "Developing A Competent 
Learner”, Industrial and Commercial Training, 2004, Vol. 36, No. 2.

Saudah, S., Tayles, M. and Pike, R., "The Impact Of Human Capital Management On Management Accounting Practices And Corporate Culture: A Study On Malaysian Companies Perspective”, International Conference on Knowledge Management, 2005, 7-9 July.

Smith, A., "The Development of Employer Training In Australia, Education and Training, 2006, Vole 48, No. 4.

Vermeulen, W. and Crous, M.J., "Training and Education For TQM In The Commercial Banking Industry Of South Africa”, Managing Service Quality, 2000, Vol. 10, No.1.

Zeti, A. A., "Islamic Finance - Promoting the Competitive Advantage", The Islamic Banker's Forum, 2005, 21 June.

Zeti, A. A., "Metamorphosis into an International Islamic Banking And Financial Hub”, ASLI's Islamic Economic Forum, 2005, Kuala Lumpur 1st October.

Zeti, A. A., "The Global Financial Services Industry", Launch of Kuwait Finance House Research, Dubai, 2007, Available at www.mifc.com/speech/2007.05.14_02_sp.pdf 